\title{
İmajlar ve Algılar Üzerinden ABD-İran İlişkileri: İlk İzlenimler (1830-1914)
}

\author{
Selin M. Bölme*
}

Öz

ABD-İran ilişkileri, uluslararası ilişkiler literatüründe dar bir zaman aralığına sıkışmış̧ır. İki ülke ilişkisi genellikle ya 1953 Mussadık darbesi ya da 1979 İslam Devrimi milat alınarak incelenmektedir. Oysa ABD'nin İran'la olan gayri resmi ilişkilerini 1830 'lara, diplomatik ilişkilerini ise 1850 'lere kadar götürmek mümkündür. İki ülkenin birbirine dair ilk izleniminin ne olduğu sorusu ile yola çıkan bu çalışma, ABD-İran ilişkilerinde 1830-1914 dönemini imaj teorisi çerçevesinde incelemektedir. Çalışma, insan ilişkilerinde olduğu gibi devletlerarası ilişkilerde de ilk karşılaşma anında edinilen imajların ve algıların uzun vadede ilişkiler üzerinde etki bırakabileceği iddiasından yola çıkmaktadır. İncelenen dönemde her iki ülkenin birbirileri hakkında sahip olduğu bilgi, İran'ınki daha az olmak üzere, son derece kısıtlıdır. ABD ve İran, benlik imajlarından, kültürlerinden, tarih bilgilerinden ve uluslararası konjektürden süzülen algıları ile birbirlerine dair gerçekçi olmayan imajlar oluşturmuşlardır. Bu gerçek dışlık iki tarafın da birbirini doğru değerlendirmesini engellemiş, yanlış beklentiler yaratmıştır.

Anahtar Kelimeler: ABD-İran İlişkileri, ABD, İran, İmaj Teorisi, İran Tarihi

* $\quad$ Dr. Öğretim Üyesi, Marmara Üniversitesi, TR, Ortadoğu ve İslam Ülkeleri Araştırmaları Enstitüsü, orcid.org/ 0000-0002-8266-4323, selin.bolme@gmail.com 


\title{
US-Iran Affairs Through Images and Perceptions: First Impressions (1830-1914)
}

\author{
Selin M. Bölme*
}

\begin{abstract}
In the international relations literature, US-Iran relations are usually examined in a narrow time frame. In these analyses, scholars examine the bilateral relationship by taking either the 1953 Mossadiq coup or the 1979 Islamic Revolution as milestone. However, it is possible to trace back the unofficial relations of the US with Iran to the 1830 s and the diplomatic relations to the 1850 s. Drawing on image theory, this study seeks to examine these two countries' first impressions of each other during the period of 1830-1914. It argues that just like in human relations, the images and perceptions states develop of one another in their first encounters can have a long-lasting impact on their relations. During the period under review, the knowledge that the two countries had of each other was extremely limited, even more so for Iran. The US and Iran had unrealistic images of each other based on their perceptions shaped by their self-images, cultures, historical information, and international conjecture at the time. These unrealistic viewpoints prevented them from assessing each other accurately and created false expectations.
\end{abstract}

Keywords: US-Iran Relations, US, Iran, Image Theory, History of Iran

Asst. Prof. Dr., Marmara University, TR, Institute of Middle East and Islamic Countries Studies, orcid.org/ 0000-0002-8266-4323, selin.bolme@gmail.com 


\section{Giriş}

Amin Maalouf'un "Semerkant" kitabının kahramanlarından Amerikalı gazeteci Benjamin O. Lesage, 1896'da gerçekleştirdiği İran seyahati sırasında Tahran'in en zengin ve önde gelen ailelerinden birinin evindeki davete çağrnlır. Davet sahibi kendisinden erken gelmesini rica etmiştir. "Bana rengarenk bahçesini göstermek istiyordu. Bir Iranl, Fazll'in babası gibi bir saray sahibi de olsa, sadece bahçesiyle övünür” sözleri ile açıklar Lesage bu erken çağrılışın sebebini. Oysa toprak zemine oturulan bahçe Lesage'1 etkilemekten uzaktır. Hayal kırıklığı satırlara "Iran bahçesinde çim bulunmaz, bu da bir Amerikalı için çoraklık demektir" cümleleri ile yansır. Maalouf'un kitabı her ne kadar tarihi kurmaca bir eser olsa da romanda Amerikalıların ilk defa İran'1, İranlıların ise ilk defa ABD'yi yakından tanımaya başladığı döneme denk düşen bu sözler, iki ülkenin zıtlıklarının, kendilerine ve birbirlerine dair algılarına şekil veren zihin dünyalarının bir özeti gibidir. Kültürler arasında derin farklılıklar olması şaşırtıcı değildir. Ancak söz konusu farklılıklar, ABD ve İran gibi çatışmaları küresel ölçekte son 40 yılı etkilemiş iki ülkeye ait ise bunu uluslararası ilişkiler boyutu ile değerlendirmek, iki ülkenin birbirlerine dair algılarını ve birbirlerindeki imajlarını da incelemek gerekmektedir. Özellikle iki ülkenin ilk imajlarının ne olduğu sorusunun cevabı, sadece ilişkilerin erken dönemini anlamak adına değil iki ülke ilişkisine geniş bir perspektif sağlayacak olması bakımından da önemlidir.

ABD-İran ilişkileri, uluslararası ilişkiler literatürünün belki de hakkında en çok üretim yapılan konularından olmasına rağmen büyük ölçüde çalışmalar dar bir zaman aralığına sıkışmıştır. ABD'de ilişkiler sıklıkla arka plana 1979 İslam Devrimi konup, rehine krizi milat alınarak anlatılırken, İran'da ise ilişkilerin tarihi genellikle 1953 Mussadık darbesi ile başlatılır. ${ }^{2}$ Oysa ABD'nin İran'la olan gayri resmi ilişkilerini 1830'lara, diplomatik ilişkilerini ise 1850 'lere kadar götürmek mümkündür. Ancak bu dönemin ilişkilerine dair çalışmalar çok kısıtlıdır. İlişkilerini imaj ve algı çerçevesinden ele alan çalışma ise yok denecek kadar azdır.

Amin Maalouf, Semerkant (İstanbul: Yapı Kredi Yayınları, 1998), 162.

John H. Ghazvinian, America and Iran: A History 1720 to Present (Londra: Oneworld Publications, 2020), 10. 
Bu çalışmanın amacı, iki ülkenin birbiri ile ilişki kurmaya başladığı yaklaşık yüzyıllık bir dönem içinde ABD ve İran'ın birbirlerine dair algılarını incelemek ve bunun çıktısı olarak karşılıklı imajlarını ortaya koymaktır. Çalışma dönemi I. Dünya Savaşı'nın başlangıcı ile sınırlandırılmıştır. Çünkü ABD'nin I. Dünya Savaşı'na girmesi, Amerikan petrol şirketlerinin İran'daki rekabete dahil olması ve Pehlevi hanedanlığının kurulması iki ülke ilişkilerini yeni bir evreye taşımıştır.

Çalışma, insan ilişkilerinde olduğu gibi devletlerarası ilişkilerde de ilk karşılaşma anında edinilen imajların ve algıların uzun vadede ilişkiler üzerinde etki bırakabileceği iddiasından yola çıkmaktadır. İncelenen dönemde her iki ülkenin birbirileri hakkında sahip olduğu bilgi, İran'ınki daha az olmak üzere, son derece kısıtlıdır. ABD ve İran, benlik imajlarından, kültürlerinden, tarih bilgilerinden ve uluslararası konjektürden süzülen algıları ile birbirlerine dair imajlar oluşturmuşlardır. Bu imajlar olumlu, olumsuz yanları ile her zaman gerçeklerle örtüşmemiş iki tarafın da birbirini doğru değerlendirmesini engellemiş ve farklı beklentiler yaratmıştır.

\section{Teorik Çerçeve: İmaj Teorisi}

Amerikalı yargıç Oliver Wendell Holmes, The Autocrat of the Breakfast Table kitabında iki kişi arasındaki geçen tartışmada aslında altı kişinin olduğu söyler: İkisi gerçekte oldukları, ikisi kendilerini gördükleri, ikisi ise birbirlerinin gördükleri kişilerdir. ${ }^{3}$ İki devlet arasındaki ilişkilerde de benzer şekilde imajlar ve algılar devreye girmekte, masaya altı kişi oturmaktadır. $\mathrm{Bu}$ da yanlış anlaşılmalara, farklı beklentilere, hayal kırıklıklarına ve hatta çatışmalara yol açabilmektedir. Uluslararası ilişkilerde devletlerin çatışmalarının kökenlerini açıklayabilme, birbirlerinin politikalarına ve eylemlerine olan tepkilerini öngörebilme ve karar alma süreçlerini anlayabilme çabası, devletlerin birbirlerindeki imajlarını inceleme konusu halini getirmiştir. $\mathrm{Bu}$ çabaların neticesinde şekillenen imaj teorisinin ana önermesi, davranışın imaja bağlı olmasıdır. Bir devletin karşısındaki aktörün imajına dair fikri, kararları ve davranışları üzerinde etkili olabilmektedir. Alanın öncü çalışmalarından birini kaleme Kenneth Boulding makalesinde, uluslararası sistemde davranışları belirleyenin

Oliver Wendel Holmes, The Autocrat of the Breakfast Table (Boston: James R. Osgood and Company, 1873), 40-41. 
gerçekler değil, imajlar olduğunu ve dünyanın aslında ne olduğuna göre değil, bize nasıl gözüktüğüne göre hareket ettiğimizi iddia etmektedir. Uluslararası sistemde iki tip önemli imaj olduğunu söyleyen Boulding, bunlardan birincisinin bir ulusun kendine dair imajı olduğunu, diğerinin ise onun uluslararası çevresini oluşturan sistemdeki diğer aktörlerin imajları olduğunu ileri sürmektedir. ${ }^{4}$ Boulding'e göre bir ulusun sistemdeki diğer aktöre dair algıladığı düşmanlık ya da dostluk, güç veya zayıflık bu aktörün o ulustaki imajının temel bileşenlerini oluşturur ve hem kendine dair imaj hem de karşı tarafa dair imaj karar alma sürecinde etkilidir. ${ }^{5}$

Dolayısı ile uluslararası sistemde bir devletin imajı sadece kendisinin politik ve diplomatik eylem ve çabalarının bir çıktısı değildir. Bu noktada algılar belirleyici rol oynar. İmajı da kapsayan daha geniş bir kavram olarak algı, hem algilama sürecini hem bu sürecin sonucunu kapsarken, imaj sadece bu sürecin çıktısı anlamına gelmektedir. ${ }^{6}$ Fisher'e göre algıyı yönlendiren öncellikle zihniyet, sonra ise meselenin nasıl sunulduğudur. ${ }^{7}$ Bu noktada algının şekillenmesinde inanç başta olmak üzere pek çok farklı faktör rol oynar ki inancı şekillendiren faktörleri de işin içine katarsak bu sayı daha da artacaktır. Bu nedenle uluslararası ilişkilerde bir aktörün dünya görüşünü veya başka bir aktöre dair algısını tanımlamak karmaşık bir iştir. Bir aktör, diğer aktörün değerlerinin neler olduğu, belirli bir bölgede nasıl bir rol oynadığ1, ekonomisinin nasıl çalıştığ 1 veya siyasi sisteminin nasıl işlediği gibi pek çok farklı konuda inanca sahip olabilir. ${ }^{8}$ Zihniyetin yanı sıra imaj teorisine göre, uluslararası ilişkilerin yapısal özellikleri de ülkelerin birbirlerine belirli imajlar tanımlamalarında önemli rol oynamaktadır. ${ }^{9}$ Bir

Kenneth Ewart Boulding, "National Images and International Systems," The Journal of Conflict Resolution 3, no. 2 (June 1959): 120-121.

5 Boulding, "National Images," 124-125.

6 Dinmuhammed Amatbek, "Perception and Image Theory of International Relations," Ankasam, 24 Temmuz 2017, https://ankasam.org/en/perception-and-image-theory-ofinternational-relations/\#_edn1

7 Glen Fisher, Mindsets: The Role of Culture and Perception in International Relations (Yarmouth: Intercultral Press, 1997), 29.

8 Richard K. Herrmann, "Image Theory and Strategic Interaction in International Relations," içinde Oxford Handbook of Political Psychology, ed. D.O. Sears, L. Huddy ve R. Jervis, (Oxford: Oxford University Press, 2003), 286.

9 Michele G. Alexander, Shana Levin ve P. J. Henry, "Image Theory, Social Identity, and Social Dominance: Structural Characteristics and Individual Motives Underlying International Images," Political Psychology 26, no. 1 (2005): 28. 
misal olarak Soğuk Savaş ortamında dost ve düşman imajlarını oluşturan diğer faktörlerden çok, sistemin yapısıdır.

Ancak sadece mevcut konjonktür imajın inşasında etkili olmaz. Özellikle ön yargılar ve şablonlar yaratan geçmiş tecrübelerin, geçmiş imajların, mevcut imaj üzerinde güçlü bir tesiri vardır. John Owen liberal barış teorisini tartıştığ makalesinde liberal devletlerin, benzer eylemlerde liberal olarak gördükleri devletlerin niyetlerini iyi olarak görürken, illiberal olarak gördüklerini ise kötü olarak gördüklerini savunmakta ve başka bir devletin düşman veya dost olarak niyetleri hakkındaki algıların, o devletin kültürüne dair daha önceden var olan imajlardan etkilendiğini ileri sürmektedir. ${ }^{10}$ İki ülkenin ilişkilerinde geçmişten taşınan imajlar gibi geçmiş deneyimler, bu deneyimlerin bıraktığı olumlu-olumsuz değerler de hedef ülkenin güncel imajını oluşturucu bir kod olarak devreye girebilmektedir. ${ }^{11}$ Bazıları böyle bir etkiyi inkar etmekte ve geçmişin algımız üzerinde etkisinin olmadığını savunmaktadırlar. Bu isimlere göre böyle bir etki varmış izlenimini yaratan, insanların kendi ön yargılarını veya bakış açılarını haklı çıkarmak için geçmiş olayları kullanmalarıdır. Robert Jervis ise bu görüşe karşı çıkmakta ve uluslararası tarihteki dönüm noktalarından öğrenilenlerin, imajları belirlemede önemli rol oynadığını ve bu imajların ise yeni bilgilere dair yorumları şekillendirdiğini ileri sürmektedir. Jervis, tarihten çıkarılan dersler çoğu zaman yüzeysel olsa da devlet adamlarının başkalarının davranışlarını yorumlarken tarihten yararlandıklarını ve bunun kendilerine bir yol belirlemede, bağlantılar kurmada ve dünyayı anlamada yardımcı olduğunu söyler. ${ }^{12}$ Burada tarihin etkisi konusunda Fisher'ın yaptığı hatırlatma da önemlidir. Bakılması gereken tarihi gerçeklerin ne olduğu değil, tarihin nasıl hatırlandığıdır; çünkü hatırlanan tarih "geçerli tarihtir."13

Yukarıda özetlenmeye çalışılan pek çok faktör algıyı etkilerken, bu alg1 diğer ulusa dair belirli imajlar veya imaj şablonları doğurur. Bu imaj

10 John M. Owen, "How Liberalism Produces Democratic Peace," International Security 19, no. 2 (1994): 87-125.

11 Betül Karagöz Yerdelen, "Uluslararası İlişkilerde İmaj Kavramı ve Batı Nostaljisindeki Bir Aksaklık Olarak Türk İmajı," Karadeniz Uluslararası Bilimsel Dergi 35, no. 35 (2017): 46.

12 Robert Jervis, Perception and Misperception in International Politics (Princeton, N.J.: Princeton University Press, 2017), 217.

13 Fisher, Mindsets, 4 ve 72. 
da karar alma sürecine etki etmektedir. İnsanın karar verme sürecinde çevresinin etkisini anlamaya çalışan Solomon Asch 1952'de Sosyal Psikoloji' deki öncü çalışmasında imajı, bir birimin temsil ettiği tehdit veya firsat, göreceli güç, göreceli kültür ile bağlantılı olarak o birim hakkında sahip olunan bütüncül yargılar kombinasyonu olarak tanımlar. Asch bu kombinasyonu 'gestalt' ${ }^{14}$ ya da betimleyici inşalar olarak tarif etmiştir. Asch' in tanımımın dikkat çekici yönü, birime dair diğer aktörün izlenimini oluşturan parçaların birbirinden bağımsız olmadığ ya da basitçe bir araya gelmediği, bunun yerine bu parçaların birbirlerini etkileyerek bütünü yani geştaltı oluşturdukları iddiasıdır. ${ }^{15}$ Asch'ın çalışmasını uluslararası ilişkiler alanına taşıyan Hermann vd, 'gestalt' yerine doğrudan 'imaj' kavramını bu anlamıyla kullanırlar. Daha önce yapılan çalışmalardan ve ana uluslararası ilişkiler teorilerininilişkileri açıklamakta merkeze koydukları kavramlardan yola çıkarak, imajın bileşsel bileşenlerini tanımlama ve şablon imajları tarif etme çabasına girerler. Burada sofistike/basit, demokratik/anti-demokratik, ileri/ilkel gibi örnekler üzerinden kültürün algılanma biçiminin imaj inşasında etkisi üzerinde özellikle durulmaktadır. Hermann, üç yargı üzerinden uluslararası ilişkilerde bir aktörün diğer aktöre dair imajı inşa ettiğini söyler: 1) algılanan tehdit/ firsat olma durumu 2) göreceli gü̧̈/ yetenek 3) göreceli kültür. ${ }^{16}$

Tüm bunlardan yola çıkarak uluslararası ilişkilerde imaj, algılayan aktörün kendine, diğer aktöre, çevrenin durumuna ve ilişkinin sistem içinde ne şekilde yürümesi gerektiğine dair sahip olduğu inançlar ve ön yargılar ile şekillenen ve buna göre farklı bileşenleri içine alan kombinasyonel inşalar olarak tanımlanabilir. Her imajın onu karakterize eden benzersiz bileşenleri vardır. Bununla birlikte bütün bu imajları kategorilere ayırarak belirli şablonlar haline getirmek dünyayı algılama ve yorumlamada belirli

14 Almancada şekil ve form anlamlarına gelmektedir. Yaygın olarak alg1, öğrenme, düşünce süreçlerini açıklamada psikolojide, sosyal psikolojide, sosyolojide kullanılan kavram özetle, bütünün parçalar demek olmadığı, bütünün parçaların toplamından daha fazla ve daha farklı olduğu savına dayanan 'bütün' kavramına karşılık gelmektedir. Irvin Rock ve Stephen Palmer, "The Legacy of Gestalt Psychology," Scientific American 263, no. 6 (1990): 84-91.

15 Solomon Asch, Social Psychology (Englewood Cliffs, NJ: Prentice Hall, 1952), 215217; Herrmann, "Image Theory," 288.

16 Richard K Herrmann, James F. Voss, Tonya Y. E. Schooler ve Joseph Ciarrochi, "Images in International Relations: An Experimental Test of Cognitive Schemata," International Studies Quarterly 41, no. 3 (1997): 409; Herrmann, "Image Theory," 286-288. 
bir düzeyde basitlik ve düzen sağlayacaktır. Bir örnek vermek gerekirse düşman imajı, aktörün tavrında, kararında veya niyetinde kötü ve agresif olduğu yorumu ile tehdit olarak görülmesine neden olur. Oysa aynı eylem benzer kapasitede bir müttefik tarafindan gerçekleştirilirse tam tersi olarak yorumlanır. Hermann'a göre uluslararası ilişkilerde beş şablon imajdan söz etmek mümkündür: Müttefik, düşman, bağımlı (sömürge), barbar (yozlaşmış), emperyalist. Eğer algılayan aktör belirli bir tip ilişki içinde olduğunu düşünüyorsa, ilişkiyi karşı taraf hakkında edindiği bir bilgiye göre bu şablonlardan birinin içine sokabilir ve kendine ve karşı tarafa dair imaj1 da bu şablon üzerinden tamamlayabilir. ${ }^{17}$

İmaj ve algıyı kendisine konu edinen çalışmalar genellikle odak noktasına dost ve düşman imajını oturtmakta, başka bir ifade ile tehdit algısının nedenleri üzerine yoğunlaşmaktadırlar. ${ }^{18}$ Bununla birlikte imajlar basitçe dost ve düşman kalıplarına indirgenemeyecek kadar çok boyut içermektedirler ve bu boyutları anlamak ilişkileri anlamlandırmada son derece önemli bir noktada durmaktadır. İmajlar tek boyutlu ve tek kaynaklı olmadıkları gibi dostluk ve düşmanlık durumlarında bile karş11ıklılık arz etmeyebilirler. Ayrıca dost ve düşman imajları zor da olsa aslında değişmesi en mümkün olanlardır. Oysa devletlerin birbirine yükledikleri imajların kültürel bileşenleri çok daha yerleşiktir ve dost veya düşman olma durumu değişse bile daha sabit olan bu parçalar çoğu zaman değişmez ve derinde ilişkileri etkilemeye devam eder. En kabaca örnekle bir Batıl1 ülke bir Ortadoğu ülkesi ile düşmanlıktan müttefiklik ilişkisine geçse bile o ülkeye dair oryantalist bakış açısı varlığını koruyabilmektedir. Dolayısıyla dost/düşman şablon imajlarının ötesinde imajları çok boyutlu incelemek uluslararası ilişkilere dair daha fazla açıklayıcılığı olan ve daha isabetli analizleri yapabilmeyi mümkün kılacaktır.

\section{ABD - İran İlişkilerinde İmajlar ve Algılar}

\subsection{Tefrikalar, Masallar: Müslüman olmayan Doğu, Vahşi Batı}

Amerikan ve İran toplumu arasında temaslar ilk defa 1800'lerin başlarında gerçekleşmiş olsa da birbirleri hakkında fikir sahibi oldukları dönemi bir

17 Herrmann, "Image Theory," 290-291.

18 Jervis, Perception, xv. 
yüzyıl önceye kadar götürebilmek mümkündür. Amerikan kolonilerindeki halkın, dönemin İranına ilgisini artıran ise ilginç bir olaydır. 1722 yazında Afgan Mahmud Hotaki liderliğinde Kandahar'daki Peştun kabileleri mezhep değiştirmeye zorlandıkları gerekçesi ile ayaklanmışlardır. Şahlık ile aralarındaki çatışmalar adeta tefrikalar halinde koloni gazetelerinde her gün yayınlanmaktadır. Olaylar halk tarafindan öyle bir merak ve ilgiyle okunmaktadır ki gazeteler haber geçmediklerinde özür dilemektedirler. $\mathrm{Bu}$ ilgi egzotik ya da oryantalist bir merakla açıklanabilecekse de asıl enteresan olan bu isyanda Amerikalıların "zorba" Mahmud karşısında İran Şahını desteklemeleridir. ${ }^{19}$ Bu yıllarda Amerikan kolonilerinin de köle isyanları ile sarsılıyor olduğu göz önüne alındığında kurulan bu empati bir yönü ile anlaşılabilir. ${ }^{20}$ Öte yandan bu desteğin siyasi ve dini temelleri de vardır. Amerikalılar Sünni Müslümanlara dair ne kadar olumsuz görüş taşıyorlarsa Şiilere karşı bir o kadar sempati duymaktadırlar. Aslında halkın İslam ya da mezhepleri hakkında çok derinlikli bilgileri yoktur. Doğu ve İslam hakkındaki kısıtlı bilgilerini ise İngiliz yazarların kitaplarından edinmişlerdir. Bu kitaplarda, Viyana kapılarına kadar dayanan Osmanlı, Hıristiyanlığa tehdit, şeytani bir imparatorluk olarak tasvir edilmekte; Türkler zalim, vahşi ve deva bulmaz şekilde şeytani kafirler olarak kınanırken, Osmanlı ile rekabette olan İranlılar ise genelde asil, cesur ve medeni bir ırk olarak anlatılmaktadır. ${ }^{21}$ Kısacası Osmanlı nefreti Sünni nefretine dönüşürken, bu Şii sempatisi doğurmuştur.

Eğitimin genelde kilise okullarından geçtiği bu dönemde, İran Şahına duyulan sempatinin Puriten kökenleri de vardır. İran, bebek İsa'ya hediyeler getiren Doğu'nun bilge üç adamı Üç Magi'nin ve Babil'i kurtaran Yahudilere özgürlüklerini veren Büyük Keyhüsrev'in toprakları olarak görülmektedir. Dinleri değiştiyse de bu zorla olmuştur. Thomas Jefferson, Voltaire'in Essay on the Manners and Spirit of Nations kitabında İran'in İslam'a geçişinin anlatıldığı kısma " $\ddot{U} c ̧$ Magi dinlerinin en kadim ve en saf olduğunu düşünüyorlardl. Matematik, astronomi ve tarih bilgileri, çok cahil olan Arap fatihler karşısında düşmanlıklarını derinleştiriyordu.

19 John H. Ghazvinian, America and Iran, 15.

20 Howard Zinn, Amerika Birleşik Devletleri Halklarının Tarihi (Ankara: İmge Kitabevi, 2005), 63.

21 Ghazvinian, America and Iran, 17. 
Yüzyıllardır kutsanmış dinlerini terk edemezlerdi" notunu düşecektir. ${ }^{22}$ Tüm bunlar birleşerek Amerikalıların zihinlerinde Şiilerin "daha az Müslüman" olduğu veya hatta hiç Müslüman olmadıkları gibi çarpık bir bilgiye dönüşmüştür. Bu nedenle Amerikan gazetelerinde İran'daki çatışma bazen Müslümanlar ve Persler arasında "kutsal savaş" olarak bile tasvir edilecektir. ${ }^{23}$

1700'lerin başında verilen bu duygusal destek ilerleyen yıllarda İran kültürüne ve tarihine duyulan ilgiyi de artırmıştır. 1765'te Harvard Üniversitesi'nde ilk defa Farsça dersleri verilmeye başlanır. ${ }^{24} \mathrm{Bu}$ halk düzeyinde popüler bir merak da değildir, ABD'nin kurucu babaları özellikle antik Pers İmparatorluğu'na hayranlık duymaktadırlar. Keyhüsrev'in kurgulasal biyografisi Cyropaedia, Aydınlanmanın da etkisi ile 18. yüzyılda sadece Avrupa'da değil Amerika'da da popüler bir kitap haline gelmiştir. ${ }^{25}$ Kitap, Thomas Jefferson, Benjamin Franklin ve John Adams'in kütüphanelerinin baş köşesindedir. Jefferson'ın kilise ve devlet ayrımı, din özgürlüğü ve seküler bir devlet fikri konularında antik Perslerden etkilendiğini kendi notlarından anlıyoruz. ${ }^{26}$ Benjamin Franklin de eğitime ve erdeme verdikleri önemden dolayı antik Perslileri överek, Amerikalıların bu örneği takip etmesini önermiştir. ${ }^{27}$ Ancak 19. yüzyıla girilirken pek çok Amerikalı İran'ın gerçekten varlığından bile hala habersizdir. Bilenler ise haritada yerini bile göstermeyecekleri bu ülkeyi Büyük İskender tarafindan yüzyıllarca önce feth edilmiş antik Pers İmparatorluğu sanmaya devam etmektedirler. ${ }^{28}$ Amerikalıların bilgilerinin çağdaş İran'a değil antik Perse dair olması aslında mevcut dönemi anlama konusunda yanılgı içine düşmelerinin de sebeplerindendir. Ghazvinian'ın tabiri ile bu dönemde az çok İran'dan haberdar Amerikalılar "kafir" Ortadoğu'nun biraz dışına

22 Richard N. Frye, "Jefferson And Cyrus: How The Founding Fathers of America were Inspired by Cyrus the Great," Richard Frye, 2013, http://richardfrye.org/files/Thomas Jefferson_and_Cyrus_the_Great.pdf.

23 Ghazvinian, America and Iran, 16-17.

24 Ghazvinian, America and Iran, 19.

25 "Cyrus Cylinder: How a Persian monarch inspired Jefferson," BBC News, 11 Mart 2013. https://www.bbc.com/news/world-us-canada-21747567.

26 Frye, "Jefferson And Cyrus."

27 Ghazvinian, America and Iran, 11.

28 Abul Kalam Azad, "Early US Economic Involvement in Iran," Probandha Sankolon /A Compilation of Essays, no. 4 (Ocak 2019): 185. 
uzandıklarını düşünmüşler, daha az Müslüman, daha az Arap, daha az şeytani bir medeniyet buldukları hissine kapılmışlardır. Bu ülke bilge ve aydın bir Şah tarafından yönetilmekte ve çıkarları örtüşmektedir. ${ }^{29}$

Amerikalıların İran'1 gazetelerden ve kitaplardan okuduğu 18. yüzy1l boyunca İranlılar, ABD bir yana Amerikan kıtası diye bir yerin varlığına bile şüpheyle yaklaşmaktadır. Çok da önem vermedikleri bu ülke zihinlerde mistik, daha çok masallarda geçen, gerçek olmayan bir yer gibidir. İranlıların çoğu, Türklerden öğrendikleri tabirle 'yeni dünya' dedikleri “yer altındaki bu vahşi diyarda" yarı çıplak yamyamların yaşadığını düşünmektedir. Eğitimli kesim arasında Amerika'nın varlığı bilinse de nasıl bir yer olduğu konusunda hemen hiçbir şey bilinmemektedir. 1809'da İran Şahı Feth Ali Şah, İngiliz diplomat Harford Jones ile Amerika hakkında sohbetinde "Ne tür bir yer orası? Oraya nasll ulaşıyorsunuz? Yerin altında mı?" diye soracaktır. Şah'ın sorularının sebebi ister cehalet ister latife olsun, aslında Amerika'yı çok da önemsediği yoktur. İran, 18. yüzyıl boyunca yaşadığı çalkantılara rağmen kendini hala dünyanın en büyük imparatorluklarından biri olarak görmektedir: "Bütün Kuzey Amerika'yı birkaç kez almaya yetecek elmaslarla süslü Tavuskuşu Tahtına oturmuş Şehinşah tarafindan yönetilen gururlu ve kadim bir uygularlıktır kendi gözünde"30

Amerika hakkında bilgisizliğin yarattığı efsaneler iki ülke arasında resmi ilişkiler kurulduktan sonra bile halk arasında devam etmiştir. İngiliz Doğu Bilimci Edward G. Browne 1893'te Tahran'dan İsfahan'a yaptığı yolculuk sırasında bir kervansarayda dinlenirken ona katılan bir katırcının yeni dünya hakkında sorular sorduğunu ve Amerikan halkının kendisiyle aynı ırktan olduğu, kendi ülkesinden oraya göç ettikleri cevabına katırcının son derece şüphe ile yaklaştığını aktarır. ${ }^{31}$ Browne'ın bir yıl süren yolculuğu boyunca pek çok İranlı kendisine sorular sormaya devam etmiştir. Browne için Zerdüştlerin Amerika'ya dair merakı daha ilginçtir "çünkü onların, bazı Müslümanlar gibi Deccal'in klyamette belirleceği İsfahan'daki kuyuya bir yeraltı tüneliyle ulaşacağını zannetmek gibi bir sebebi de

29 Ghazvinian, America and Iran, 18-19.

30 Ghazvinian, America and Iran, 22-23.

31 Edward Granville Browne, A Year Amongst the Persians: Impressions as to the Life, Character \& Thought of the People of Persia, Received During Twelve Months' Residence in That Country in the Years 1887-1888 (Londra: Adam and Charles Black, 1893), 172. 
yoktur." ${ }^{2}$ İran halkının Amerika'ya dair cehaleti uzun y1llar devam etse de 1830'da Amerikan misyonerlerin İran'a gelişi ile beraber en azından kuzey İran'dan yayılan bir şekilde ABD hakkında bilgi artmaya başlayacaktır. ABD'nin bağımsızlığı için İngiltere'ye karşı savaştığı bilgisi, daha başından İngiltere'den zaten nefret eden İranlılar için olumlu bir imaj yaratacaktır. ${ }^{33}$

\subsection{Misyonerler ve İranlılar: Hayranlık ve Hoşnutsuzluk Arasında}

Amerikan Protestan misyonerleri, kültürel bir etkileşim süreci başlatarak iki ülkeyi tefrika ve masalların ötesine geçirmiş, ABD-İran ilişkileri üzerinde köklü bir miras bırakmışlardır. Amerikan misyonerliği faaliyetleri, Washington'ın İran'a karşı son derece ilgisiz olduğu bir dönemde, keşif amacı ile bölgeye giden ilk misyonerlerin yoğunluklu olarak Süryanilerin yaşadığı kuzeybatı İran'a 18 Aralık 1830'da ulaşması ile başlamıştır. Bu keşif gezisini takiben bir Süryani şehri olan Urmiye'ye yerleşmişler ve Papaz Justin Perkins tarafindan daha sonra içinde kütüphane, hastane, okul ve matbaa inşa edilecek olan ilk daimi misyon merkezi 1835 'te kurulmuştur. ${ }^{34}$ Misyonerlerin İran'a geliş amacı temelde İncil'i yaymak ve Doğu kilisine bağlı Hıristiyanları Protestan yapmak ve Müslüman halka din değiştirtmek olsa da bu nihai hedef içinde bir "medeniyet götürme" misyonunu da barındırmaktadır. Zirinsky, İranlıları "modern" Bat1 medeniyeti ile tanıştırmayı amaçlayan misyonerlerin, İran' da eğitim, toplum ve siyaset alanında hayal ettiklerinin Amerika için ön gördüklerinden farklı olmadığını söyler. Bu, Hıristiyan, bilime dayanan, dinamik, yardımsever ve demokratik bir halk yaratmaktır. ${ }^{35}$ Amerikan Misyonunun din ve

\section{Browne, A Year, 437-438.}

33 Kamyar Ghaneabassiri, "U.S. Foreign Policy and Persia, 1856-1921," Iranian Studies 35, no. 1/3 (Kış/Yaz, 2002): 148.

34 Michael P. Zirinsky, "Render Therefore Unto Caesar the Things Which Are Caesar's: American Presbyterian Educators and Reza Shah," Iranian Studies 26, no. 3/4 (1993): 337; Abul Kalam Azad, "The Legacy of the American Presbyterian Mission in Iran," Journal of the Asiatic Society of Bangladesh 58, no. 1 (2013): 192-193; Lydia Wytenbroek, "Generational Differences: American Medical Missionaries in Iran, 1834-1940," içinde Iran and the West: Cultural Perceptions from the Sasanian Empire to the Islamic Republic, ed. David Bagot ve Margaux Whiskin, (Londra. New York: I.B. Tauris, 2018), 179.

35 Michael P.Zirinsky, "A Panacea for the Ills of the Country: American Presbyterian Education in Inter-War Iran,” Iranian Studies 26, no. 1/2 (1993): 119, Zirinsky, "Render Therefore," 337. 
medeniyet temelli bu iki gayesi, İran halkında Amerikalılara ve ABD'ye dair birbirine tamamen zıt iki imaj yaratacaktır. Bununla birlikte İranlıların hayranlıkları, hoşnutsuzluklarına ağır basacaktır.

Misyonerlerin de İran ve İranlılara dair kafaları karışıktır. Benzer şekilde duyguları başlangıçtan itibaren hayranlık ve hoşnutsuzluk arasında bölünmüştür. Misyonerler İran'a ülke, kültürü, halk1 ve kurumları hakkında kesin önyargılarla gelmişlerdir. Kuşkusuz İran'da geçirdikleri zaman içinde yeni tecrübeler ve bilgiler edinmiş olsalar da başlangıçtaki zihniyetleri algılarını her dönem etkileyecektir. ${ }^{36}$ İran halkına bakışları çok da şaşırtıcı olmayan bir şekilde etnosentriktir. Bir yandan İran'ın antik tarihinden, egzotikliğinden ve geleneklerinden etkilenirken, öte yandan Müslüman çoğunluğa üstünlük duygusu ile bakmaktadırlar. Bu daha çok iki zit duygunun çatışması gibidir. Kimi zaman bu duygusal bölünme daha somut şekilde misyonerler arasında kendini göstermektedir. Kendini İranlı hissedenler, İran'a hayranlık duyanlar ve tüm ömrünü İran'da geçirenler kadar İran'dan nefret edenler de vardır. James Bill'e göre İran kültürüne duyulan hayranlık ve saygı, din söz konusu olduğunda üstünlük duygusu altında ezilmekte ve küçümsemeye dönüşmektedir. Bu sadece Müslümanlara karşı değil ayrıca bölgedeki Süryani Hıristiyanlara karş1 da böyledir. ${ }^{37}$ Daha misyon kurulmadan 1819'da yazılan İran'a ilişkin ilk raporlardan birinde, bölgedeki halkın acınacak bir cehalet ve yozlaşma içinde ilahi bilgiden yoksun olduğu ve bölge boyunca uzanan komşuları gibi İran halkının da "boş hayallerle ve güçlü sanrılarla sersemlemiş," neredeyse bir parça ruhani aydınlanma için Amerika'ya yalvarır halde olduğu yazmaktadır. Keşif için gelen ekibin izlenimleri de farksızdır. Sadece birkaç hafta bölgede bulunmuş olmalarına rağmen rapora kesin yargılarla "asil ancak cahil bir halk" olarak tanımladıkları Süryanilerin zar zor anladıkları Hıristiyan ayinlerini devam ettirdiklerini ve neredeyse Amerikan kurtarıcılığ 1 için "yalvardıklarını" yazmışlardır. ${ }^{38}$ Benzer şekilde misyonun ilk doktoru Asahel Grant, 1841'de Süryani toplumu hakkında yayınladığı kitabında Amerikalılardan "daha az medeni” ve "ilkel

36 Zirinsky, "Render Therefore," 338.

37 James A. Bill, The Eagle and the Lion: The Tragedy of American Iranian Relations (New Haven: Yale University Press, 1989), 15.

38 Ghazvinian, America and Iran, 24-25. 
Hıristiyanlar" olarak tanımladığı Süryanilerin "cehaletin ve batıl inançların karanlığına gömülmüş” olduğunu söylemektedir. ${ }^{39}$

Misyonerlerin çoğu İranlı Hıristiyanların çürümüş bir kilisenin mensupları olduğuna inanmakla birlikte onlar din kardeşleridir. İncil'e ihtiyaç duyan kafirler olarak gördükleri Müslümanlara karşı duyulan küçümseme bu nedenle çok daha derindir. ${ }^{40}$ Misyonun başında bulunan, yaşadığ Süryanilerin gelenekleri ile kendini özdeşleştirmiş ve İran toplumuna yakın bir isim olan Papaz Justin Perkins'in notlarında bu ayrımı görmek mümkündür. Perkins, İranlıların "zeki ve meraklı", "nazik ve konuksever" olduklarına inanırken, aynı zamanda halkın çoğunluğunu oluşturan Müslümanların "genel ahlaki yozlaşmaları dehşet verici" boyutta olan “vahşi Muhammediler” olduklarını düşünmektedir. Perkins İslam'1 "kibirli, münhasır, yozlaşmış, kindar ve kanlı" olarak tasvir etmektedir. ${ }^{41}$ Misyonun, mezhep/din değiştirtme odaklı yapısı, İran toplumuna etnosentrik bakışı ve üstünlük duygusu kaçınılmaz olarak halk ile ilişkilerinde gerginlik yaratacaktır. İranlılar zaman içinde her ne kadar misyonerlerin eğitim, sağlık ve yardım faaliyetlerinden memnun olsalar ve ABD'nin yeteneklerini, teknolojik açıdan ileri olmasını takdir etseler de her anlamda küçük görülmekten ve kendi dinlerinin yanlış olduğunun söylenmesinden fazlasıyla rahatsızdırlar. ${ }^{42}$ Misyonlerin yaklaşımlarındaki en temel sorun İran halkına, geleneklerine, değerlerine ve dinlerine saygısızlık içinde olmaları ve bunun farkında dahi olmamalarıdır. Bu yaklaşımları en seküler faaliyetlerine bile uzun süre din çatışmasını bulaştıracaktır.

ABD elçisi Samuel Benjamin 1886'da kaleme aldığı makalesinde, İran yönetimi tarafından misyonerlerin Müslümanlara yönelik din değiştirme faaliyetlerinin kesinlikle yasaklanmış olduğunu yazar. ${ }^{43}$ Misyonerlerin bu dönemde Hıristiyanlara yönelik mezhep değiştirtme politikaları da ikinci planda kalmıştır. Rostam-Kolaji, 19. yüzyılda misyonerlerin gayesinin İran halkını, özellikle Hıristiyanları protestanlaştırmakken, 20. yüzyılda

\footnotetext{
39 Wytenbroek, "Generational Differences," 181.

40 Zirinsky, "Render Therefore," 338.

41 Ghaneabassiri, "U.S. Foreign Policy," 149.

42 Zirinsky, "Render Therefore," 355; Bill, The Eagle and the Lion, 15; Azad, "The Legacy," 201, 204.

43 Samuel G.W. Benjamin, "Persia and the Persians," Journal of the American Geographical Society of New York 18, (1886): 44.
} 
odak noktalarının sağlik ve eğitim gibi alanlarda modern bir hizmet sunmak olduğunu söylemektedir. ${ }^{44} 19$. yüzyılın sonlarından itibaren bu etki gözlemlenebilir. Hıristiyanlığın gereklerini kamu hizmeti ile ifa etmek gerektiği fikrinden ağılıklı olarak etkilenen ikinci nesil misyonerler, İran halkına hizmeti İncil'in bir ifade ediliş biçimi olarak görmüşlerdir. ${ }^{45} \mathrm{Bu}$ anlamda ikinci nesil misyonerler hoşnutsuzlukları azaltarak, Amerikalılara duyulan hayranlık ve sempatiyi artırmışlar ve müşfik, yardımsever, diğer Batılı ülkelere benzemeyen ABD imajını güçlendirmişlerdir.

Her ne kadar arkalarında bir devlet desteği olmasa da Ghazvinian isabetli bir şekilde tespit ettiği gibi bu misyonerlerin çalışmaları Amerikan yumuşak gücünün Ortadoğu'daki ilk tatbikidir. ${ }^{46}$ Amerikan misyonerlerinin en büyük avantajı İran'da ABD hakkında çok az şey bilinmesi ve ABD'nin İran'a yönelik bir politikasının olmamasıdır. 1922-1927 ve 1943-1944 yılları arasında İran'a mali danışmanlık yapmış olan Arthur C. Millspaugh bu durumu şu sözlerle özetlemektedir:
Íkinci Dünya Savaşına kadar, Aslan ve Güneş Ülkesi ABD’nin siyasi ufkunun ötesinde ve neredeyse bilgisinin dişındaydı. Bu gerçeğe rağmen ya da daha çok bu yüzden, Amerika ve Amerikalılar Iranlıların zihininde ve umutlarında özel bir itibara ve özel bir ilişkiye sahip oldular. ${ }^{47}$

İranlıların gözünde misyonerlerin görünüşleri Avrupalılara benzemekte, Avrupalılargibi konuşmakta, Avrupalılargibi giyinmektedirler fakattavırları ve İranlılara karşı davranışları Avrupalılar gibi değildir. Devletlerinin İran hükümetinden herhangi bir talebi yoktur, bir anlaşma dayatmaya çalışmamaktadır ve hatta bir elçi bile göndermemiştir. Açıklanamaz bir nedenle Amerikalılar İranlılara sadece yardıma gelmişlerdir. ${ }^{48} \mathrm{Bu}$ durum, sadece İran Devleti'nin ve halkının ABD'ye yakınlık duymasına değil aynı zamanda Amerikan devletinin de kendilerine sempati duyduğuna

44 Jasamin Rostam-Kolayi, "From Evangelizing to Modernizing Iranians: The American Presbyterian Mission and Its Iranian Students," Iranian Studies 41, no. 2 (2008): 214.

45 Wytenbroek, "Generational Differences," 180-181, 186-187.

46 Ghazvinian, America and Iran, 24.

47 Abul Kalam Azad, "Iran-United States Relations Since 1945," (Doktora Tezi, University of Dhaka, 2017); Arthur C. Millspaugh, Americans in Persia (Washington, D. C: The Brookings Institution, 1946), 7.

48 Ghazvinian, America and Iran, 32. 
inanmalarına yol açacaktır.

Misyonun en önemli faaliyet alanlarından biri, ana hedefi Amerikan kültürünü ve değerlerini yaymak olan eğitim olmuştur. Her ne kadar İran'da modern eğitim üzerinde Fransızların büyük etkisi olsa da ilk modern eğitim veren okulları Amerikalılar açmıştır. ${ }^{49}$ Bu nedenle 18981941 yılları arasında İran' da yaşayan, erkek öğrenciler için kurulan Tahran Amerikan Lisesi'nin ve daha sonra Tahran Amerikan Kolejinin (Alborz Koleji) müdürü olan Dr. Samuel Martin Jordan pek çok açıdan İran'da modern eğitimin kurucusu olarak da kabul edilmektedir. Misyonerlerin ilk erkek okulu Urmiye'de 1836 'da, ilk kız okulu ise 1838 'de açılır. Yoğun bir şekilde okul kurmaya başlayan misyonun 1841 'de 17 olan okul sayısı, 1851 'de 45 'e çıkmıştır. 1860 'ta 1500 İranlı öğrenci misyoner okullarında okumaktadır. 1895'e gelindiğinde ise sadece Urmiye'de 117 misyon okulu bulunmaktadır. ${ }^{50}$ Misyon okullarına yalnız Hıristiyan ailelerin çocukları değil, Şah'ın ailesinin, hükümet görevlilerinin, toprak sahiplerinin ve tüccar sınıfinın çocukları başta olmak üzere Müslüman çocuklar da gitmişlerdir. 1891'da Tahran Amerikan Koleji'nin 135 öğrencisinin yarısından fazlası Müslümandır. ${ }^{51}$ Bu dönemde İran'da İngiltere, Rusya, Fransa ve Almanya da okullar açtıysa da ülkenin ileri gelenleri çocuklarını Amerikan okullarına göndermeyi tercih etmişlerdir. ${ }^{52}$ Özellikle kız çocuklarının eğitimindeki rolleri nedeniyle İran'da önemli etkiler bırakmışlardır. Bununla birlikte misyoner okullarının hem İran toplumunu etkilemedeki rolü hem de Amerikan imajını inşa etmedeki rolleri dikkatle ele alınması gereken konulardır. Bunun bir nedeni, bu okullara giden öğrencilerin farklı etnik, dini ve sınıfsal gruplardan gelmeleri ve okulların yüzyılı aşan bir zaman dilimi içinde faaliyet göstermiş olmalarıdır. Bazı öğrenciler üzerinde etkilerinin daha fazla olması kaçınılmazdır ancak okulları doğrudan Amerikan değerlerini toplum içinde yayan kanallar olarak görmek doğru

49 Rostam-Kolayi, "From Evangelizing,” 213.

50 Ghaneabassiri, "U.S. Foreign Policy," 150-151; Rostam-Kolayi, "From Evangelizing," 216; Bill, The Eagle, 17.

51 Azad, "The Legacy," 197; Ali Gheissari, "The American College of Tehran, 1929-32: A Memorial Album," Iranian Studies 44, no. 5 (2011): 672.

52 Ramin Asgard, "U.S.-Iran Cultural Diplomacy: A Historical Perspective," Al Nakhlah (Spring 2010). https://ciaotest.cc.columbia.edu/journals/aln/aln690/f_0019356_16566. pdf., 3 . 
olmayacaktır. ${ }^{53}$ Nitekim eğitim faaliyetinin tamamen sorunsuz geçtiği de söylenemez. Hem İran hükümetleri hem de halk zaman zaman bu okullara şüphe ve hoşnutsuzlukla yaklaşmışlardır. ${ }^{54} \mathrm{Bu}$ nedenle misyonun eğitim faaliyetleri $\mathrm{ABD}$ ve Amerikan değerleri hakkında bilgiyi artırmakla birlikte, ABD'ye esas itibar kazandıran bu okulların modern eğitimin yolunu açmış olmaları ve İran toplumuna fayda sağlamalarıdır.

İran'daki Amerikan misyonerleri sadece eğitim değil sağlik alanında da köklü etkiler bırakmışlardır. İranlıların kalbini kazanmada misyon doktorlarının özel bir yeri vardır. 1878'de Urmiye'de ilk hastaneyi kuran ve 1879 'da Batı tarzı ilk tıp okulunu açan misyon doktorlarından Joseph Cochran verdiği hizmetlerle yerel bir kahramana dönüşecektir. Öyle ki 1905 'te öldüğünde on binlerce yas tutan İranlı cenazesinde sokaklara dökülmüştür. ${ }^{55}$ Misyon tarafindan ilk modern Amerikan hastanesi 1882'de yine Urmiye'de açılır. Hastanenin açıldığı yıl patlak veren kolera salgını 1904 'te tekrarlamış ve her iki salgının da atlatılmasında Amerikan hastanesi ve doktorları kritik rol oynamışlardır. Kolera salgınları sırasındaki fedakarca çabaları ülke çapında takdir görmelerini sağlamış, misyon İran hükümetinin de övgüsüne mazhar olmuştur. Zaten hem Nasırüddin Şah'ın hem Muzafferüddin Şah'ın özel doktorları misyon doktorlarıdır. ${ }^{56}$ 1920'lere gelindiğinde Amerikalı doktorlar Tahran'da, Reşt’te, Hamandan, Tebriz, Kermanşah ve Meşhed'deki hastanelerde çalışmaktadırlar. ${ }^{57}$

Misyon faaliyetlerinin faydalı sonuçları hem misyonerlere pek çok İranlının destek ve saygısını kazandırmış hem de bütün bu süreç ABD'ye şöhret ve itibar getirmiştir. Yardım faaliyetleri, okulları, hastanelerinin yanı sıra çok çalışmaları ve azimleri İranlılara ABD'ye dair fedakarlık ve iyi niyet üzerine kurulu bir kültürel imaj sunmuştur. Misyonerler açısından tüm bu faaliyetler İran toplumuna Amerikan değerlerini ve ABD'yi tanıtmanın bir yolu olmuştur. Amerikan toplumunun ileri kültüründen, endüstri devriminden ve onu takip eden teknolojik gelişmelerden bahseden misyonerler, anlattıkları eşitlik, özgürlük, firsatların herkese açık

\footnotetext{
53 Gheissari, “The American College,” 676-677.

54 Rostam-Kolayi, "From Evangelizing,” 214, 220.

55 Ghazvinian, America and Iran, 28.

56 Azad, "The Legacy," 197.

57 Wytenbroek, "Generational Differences," 185, 187-188.
} 
olması, Amerikan kadınının özgürlüğü gibi konularla İranlıların gözünde takdir edilen, "iyicil” bir ABD imajı çizmişlerdir. Ghaneabassiri'nin de belirttiği gibi bu aslında ABD'ye dair bir illüzyondur. ${ }^{58}$ Gerçekten de bu dönem Amerikan imajını inşa eden her türlü bilgi misyonerlerin bireysel çabalarının bir sonucudur ve ABD'nin bu çabaları planlaması, yürütmesi veya desteklemesi söz konusu değildir. 1883'e kadar ABD Tahran'a resmi bir diplomatik temsilci bile göndermeyecektir. Nadir durumlarda İran'daki Amerikalılar başları derde girdiklerinde İngiliz diplomatlarından yardım istemektedirler. ${ }^{59}$

Misyonerlerle Amerikan devletinin özdeşleştirilmesinin neticesinde doğan ABD imaj1, İran'1 gerçekçi olmayan beklentilere sokacaktır. Öte yandan bu illüzyon tek taraflı değildir. Amerikan misyonu sadece İran'da ABD imajının oluşmasında değil aynı zamanda ABD'de İran imajının oluşmasında da etkin bir rol oynamıştır. Misyon, misyonerlerin yayınladıkları raporlar ve kitapların yanı sıra ABD'ye İranlıları davet ederek Amerikan halkının da İran'ı tanımasının yolunu açmıştır. 1841'de Urmiye Süryani Piskoposu Mar Yohannan'in ABD ziyareti öyle ilgi çekecektir ki bir sene süren Amerika turu boyunca yaptığı konuşmalara "bu egzotik cübbeli, uzun sakallı ve gösterişli ipek sarıklı İranlı vaizi" görmek isteyen binlerce meraklı Amerikal1 katılacaktır. Bu ziyaretler İran'1 ete kemiğe büründürdüyse de aynı zamanda egzotik ve etnosentrik bir çembere de sokmuştur. Misyonerlerin İran'a dair perspektifleri kuşaklar boyu Amerikalıları etkilemiştir. Bu sadece toplumsal değil siyasi de bir etkidir. Misyonerler iki ülke arasında önce gayri resmi arabuluculuk rolünü üstlenmişler daha sonra İran ile resmi diplomatik ilişkileri dolaylı olarak domine etmişlerdir. 1950'lere kadar İran ile ilişkilere bakan diplomatların çoğunun ya kendisi eski bir misyonerdir ya eski bir misyonerin çocuğudur ya da bir şekilde Protestan misyonerlerinin faaliyetlerinden derin şekilde etkilenmiştir. ${ }^{60} \mathrm{Bu}$ da her ne kadar ilişkileri yakınlaştıran bir faktör olarak karşımıza çıksa da püriten bakış açısı ile çizilen İran imajının, hayranlık duyulan ancak İslam'ı dişlayan İran'ın kültürel tasvirinin Amerikan diplomasininde yer edinmesine yol açmıştır.

\footnotetext{
58 Ghaneabassiri, "U.S. Foreign Policy,” 148.

59 Ghazvinian, America and Iran, 30.

60 A.g.e., 29.
} 


\section{3. İran'ın Amerikan Rüyası, ABD'nin İran Gerçeği}

\subsection{1. Şahların Amerikası}

Amerikan misyonerlerinin İran topraklarında faaliyetlerini geniş bir alana yaymalarını sağlayan en önemli etmenlerden biri Muhammed Şah'tan (1808-1848) itibaren İran Şahları tarafından büyük ölçüde destek görmüş olmalarıdır. Nasırüddin Şah (1848-96) misyonerlerin faaliyetlerini sinırlandırması yönünde yerel ulemadan, tüccarlardan ve Ermeni Kilisesi liderleri başta olmak üzere dini-etnik azınlıklardan baskı görmesine, hatta faaliyetlerine müdahale etmiş olmasına rağmen misyonerler bu dönemde tehditlerden korunmuş, destek görmüş ve faaliyetlerini İran'ın kuzeyini aşan şekilde genişletmişlerdir. ${ }^{61}$ Bunun önemli nedenlerinden biri 19. yüzyıl başlarından itibaren İran üzerindeki Rusya, İngiltere ve hatta diğer Avrupalı güçlerin nüfuz mücadelesinden boğulan Nasırüddin Şah yönetiminin, bunları dengeleyici üçüncü bir güç olarak ABD'yi görmeye başlaması ve ABD ile özdeşleştirdiği misyonerlere iyi bir evsahipliği yapma çabasıdır. ${ }^{62} 1828$ Türkmençay Anlaşması sonrasında Rusya'nın elde ettiği kapitülasyonların örnek teşkil etmesi ile İngiltere başta olmak üzere 1855 ile 1900 yılları arasında 50'den fazla Avrupa ülkesi İran'dan ayrıcalıklar talep elde etmiştir. ${ }^{63}$ Bu İran'ı kaosa sokarken, İran hükümetinin ABD'yi siyasi, ekonomik ve teknolojik destek almak için ikna etme çabası ile paralel olarak Amerikan misyonlarının faaliyetlerine verdiği izinler 1800 'lerin ortalarından sonra gittikçe artmıştır. ${ }^{64}$ Kısacası misyonerler bir yandan İran'ın gözünde ABD'nin değer ve kültür temelli imajını inşa ederken, bununla birleşen uluslararası konjenktür İran'ın ABD'yi firsat olarak görüp 'dengeleyici güç' olarak yeni bir rol biçmesine neden olmuştur. Dolayısıyla dönemin Amerikan imajının bu ögeleri, biri ötekinin sonucu olmamakla birlikte eş zamanlı olarak birbirlerini beslemişler ve Amerikan imajını yaratmışlardır. Bu Amerika ekonomik olarak güçlü, teknolojik olarak ileri, yardımsever, eski güçlere karşı ezinlen devletlerin yanında yer alan, emperyal amaçları olmayan bir devlettir.

\footnotetext{
${ }_{61}$ Rostam-Kolayi, "From Evangelizing," 217-218; Azad, “The Legacy,” 196.

62 Mansour Bonakdarian, "U.S.-Iranian Relations, 1911-1951," içinde The United States and the Middle East: Diplomatic and Economic Relations in Historical Perspective, ed. Abbas Amanat (New Haven: Yale University Press, 2000), 10; Bill, The Eagle, 17,

63 Ghazvinian, America and Iran, 32.

64 Azad, "The Legacy," 197.
} 
ABD dostluğunun İran'a sağlayabileceği avantajları ilk fark eden Nasırüddin Şah'ın 1848'de başbakan olarak atadığı Emir-i Kebir lakab1 ile de bilinen reformist Mirza Taki Han'dır. Mirza Taki Han İngiltere'ye karşı savaşmış ABD'nin İran'ı anlayabileceğini düşünmektedir. Ayrıca bu dostluk Batı medeniyetinin teknolojisini, bilgi birikimi ve üstünlüklerini çıkarcılık ve açgözlülük olmadan ülkeye taşımanın, modenleşmenin ve tam bağımsızlığı elde etmenin bir yolu olarak görülmektedir. ${ }^{65} \mathrm{ABD}$ 'nin bir sömürgecilik yarışı içinde yer almaması ve bölgede geçmişinin olmaması diğer büyük güçlerden farklı olduğu inancını kuvvetlendirmiştir. Kabir k1sa süre görevde kalsa da ABD'nin “iyi büyük güç” olduğu görüşü hem Şah yönetimi tarafindan kabul görecek hem de 1906 Devrimi sürecinde meşrutiyetçiler tarafindan da benimsenecektir. $\mathrm{Bu}, \mathrm{ABD}$ ile ittifakı hiç bir Batılı ülkeye nasip olmayacak şekilde İran'da farklı güç gruplarının uzlaşı noktası haline getirecektir. 1951'e kadar çoğu İranlı "pozitif denge" ya da "üçüncü güç stratejisi”" olarak tanımlanan ABD ile yakın ilişkilerin korunmasına gerektiği inancını paylaşmaya devam edecektir. ${ }^{66}$

İran'ın çabaları sonucunda ABD ve İran temsilcileri ilk defa 1849'da İstanbul'da bir araya gelmişlerdir. Şah yönetimi bu görüşmelerden umutludur. ABD'nin güçlü bir müttefik olarak dengeleyeci bir rol üstlenmesi, karşıllı̆ını ise adil bir ticaret ile alması beklenmektedir. Ancak 1850'lerin başlarında İran Körfezi'nde ticareti gittikçe büyüyen ABD'nin motivasonu sadece ticarettir. ABD, George Washington'un 17 Eylül 1796' da başkanlığa veda konuşmasında "Yabancı ülkelerle ilgili bizim takip ettiğimiz en önemli ilke, ticari ilişkilerimizi genişletirken, onlarla siyasi ilişkilerimizi mümkün olduğunca asgari düzeyde tutmaktır" 67 sözleri ile ilk çerçevesini çizdiği izolasyon politikasına sonuna kadar bağlıdır. Ayrıca İran'ın sandığ 1 kadar emperyalist gayelerden uzak da değildir. Bu dönemde ABD'yi diğer Avrupalı güçlerden ayıran tek şey coğrafi yayılmasını kendi kıtasında tutması ve mümkün mertebe savaşa başvurmadan ticaretini genişletme motivasyonu ile hareket etmesidir. 1848 Meksika Savaşı

65 Abbas Amanat, Pivot of the Universe: Nasir al-Din Shah Qajar and the Iranian Monarchy (18311896) (Londra: I.B. Tauris, 1997); 287-289, Ali M. Ansari, Modern Iran since 1797: Reform and Revolution (New York: Routledge, 2019), 74.

66 Bonakdarian, "U.S.- Iranian Relations," 10.

67 "George Washington Farewell Address," United States Senate, Son erişim: 08 Şubat 2021. https://www.senate.gov/artandhistory/history/resources/pdf/Washingtons_Fare well_Address.pdf. 
öncesi ülke içinde yapılan tartışmalar ticaret için gerekirse savaş yoluyla genişlemeyi tercih edenler ile genişlemeyi fikirlerin gücü ve ticaret baskısı ile yapma taraftarları arasında gidip gelmektedir. ${ }^{68} \mathrm{Bu}$, İran'ın bildiği ABD değildir. Bu nedenle 1851'de iki ülke temsilcilerinin imzaladıkları ticaret anlaşmasının 'en çok kayrılan devlet statüsü' verilmediği gerekçesi ile Amerikan Kongresi tarafından reddilmesi İran'da şaşkınlık ve hayal kırıklığı yaratmıştır. Diğer Batılı ülkeler gibi olmadığı düşünülen ABD aynı imtiyaz ve ayrıcalıkları talep etmektedir. İran, o anlaşmaların yenilgiler ya da borçlar nedeniyle imzalandığını ve dost bir ülke ile imzalanırsa Türkmençay Anlaşması'ndan bile kötü sonuçları olacağını çünkü tüm ilişkilerinde imtiyaz taleplerine örnek teşkil edeceğini söylese de $\mathrm{ABD}$ 1srarından vazgeçmeyecektir. $\mathrm{Bu}$ süreç içinde İran ABD'nin önüne, İngiltere'ye karşı bir askeri ittifak yapma seçeneğinden, Amerikan donanmasının İran ticaret gemilerini korumasına kadar çeşitli askeri ve siyasi anlaşmaları getirdiyse de Amerikan yönetiminin tek ilgilendiği imtiyazlar olmuştur. ${ }^{69}$ Gelecekte güçlü bir ittifaka dönüşmesi umudu ile ABD'nin talebi kabul edilerek ABD-İran Dostluk ve Ticaret Anlaşması 13 Aralık 1856 ' da İstanbul'da imzalanmıştır. ${ }^{70}$ Belki de en ilginç olanı hayal kırıklığı yaratan bu başlangıca rağmen İran'ın ABD'den umudunu yitirmemesidir.

Ticaret söz konusu olduğunda ABD her zaman hevesli olmasına karşın İran ile ilişkileri oldukça yavaş gelişmiştir. Bu durgunluğun arka planında ABD'nin $1860-1865$ 'te iç savaş ve 1873 'te ekonomik kriz yaşaması ve toparlanma sürecinde olması yatmaktadır. Ancak daha önemlisi coğrafi olarak uzak olan bu topraklara Amerikan özel sermayesi açılma konusunda tutuk, Amerikan devleti ise İngiliz ve Rus çıkarlarına zarar vermeme adına temkinlidir. ${ }^{71}$ Bir anlamda İran, ABD için beklemede olan bir pazar niteliği taşımaktadır. Tek başına daha fazla bir anlam da ifade etmemektedir. ABD için kendi sorunları bir yana İran için katı izolasyoncu politikasını bozarak, Avrupa çatışmalarına girmeyi düşünderecek caziliplikte birşey de görmemektedir. Ancak İran yönetimi bunu anlamamakta, ABD'nin ikna edilebileceğini düşünmektedir. $\mathrm{Bu}$ güvenin ardında yatan neden

\footnotetext{
68 Zinn, Amerika Birleşik Devletleri, 159-177.

69 Bonakdarian, "U.S.-Iranian Relations," 10; Ghazvinian, America and Iran, 33-35.

70 Azad, "Early US," 186.

71 Amanat, Pivot of the Universe, 287-289.
} 
sadece ABD'ye yüklenen iyicil rol ve İran'ın sunduğu cazip ekonomik imtiyazlar değil aynı zamanda İran'ın gurur duyduğu köklü imparatorluk geçmişidir. ABD yeniyi, İran eskiyi temsil etmektedir ve Amerikalıların yeni olmakla gururlu olduğu kadar İranlılar da eski olmakla gururludur. İran'ın ilk ABD elçisi Hüseyin Ali Han Nuri'nin 1888'de ABD Başkanı Grover Cleveland'a okuduğu Şah'ın mektubundaki ifade ile "köklü ve bağımsız Pers İmparatorluğu", "genç ve müreffeh ve zengin kız kardeşine" seslenmektedir. ${ }^{72} 1856$ Anlaşması'nın başında geçen ünvanlar bu durumu daha çarpıcı bir şekilde gözler önüne sermektedir:

Amerika Birleşik Devletleri Başkanı ve mertebesi Zühal gezegeninde olan Majesteleri; Güneşin kendisine sancak olduğu Hükümdar; görkemi ve ihtişamı göklere eş; orduları yıldızlar kadar çok olan Şah, Haşmetmeab; yüceliği akıllara Cemşid'i getiren; muhteşemliği Darius'a eş; Keyani Tacının ve Tahtının varisi; bütün İran'in Haşmetli Imparatoru. ${ }^{73}$

Ancak İran gibi güçten düşmüş bir ülkenin bu ihtişamlı sözleri Amerikalılara bir anlam ifade etmez. Nitekim İstanbul büyükelçisi Carroll Spence, 1856 Anlaşmasının imzası ardından İranlıların teşrifatın bir parçası olarak değerli hediyeler bekleyeceğini ABD Dişişlerine açıklamakta zorluk çekmiştir. Kendini alçak gönüllü, pragmatik ve eski dünyanın dalkavukluklarından uzak görmeyi seven $\mathrm{ABD}$, bu protokol gösterilerinden etkilenmek bir yana saçma bulmaktadır. Tartışmaların neticesinde Şah'a pırlantalarla süslü enfiye kutuları ve silahlar hediye edilir. Bu İran tarafında inanılmaz bir memnuniyet ve umut yaratır. Ancak daha sonra ilişkilerde hiç bir gelişme olmaması İran'1 şaşkınlığa sokacaktır. Amerikalıların o kadar pahalı hediyeyi neden verdiklerine bir türlü anlam verilemez. ${ }^{74}$ Amerikalılar paralarını boşa harcamak olarak görseler de teşrifatı yerine getirmişler ama arkasındaki anlamı çözememişlerdir.

Benzer bir zıtlıklar seramonisini iki ülkenin karş1lklı temsilcilikler ${ }^{75}$ açmasının akabinde yaşanan süreç içinde de görmek mümkündür.

72 Ghazvinian, America and Iran, 48.

73 "Iran: Friendship and Commerce," 13 Aralık 1856, Library of Congress, Son erişim: 16 Şubat 2021. https://www.loc.gov/law/help/us-treaties/bevans/b-ir-ust000008-1254.pdf.

74 Ghazvinian, America and Iran, 35.

75 ABD ile İran arasında ilişkiler büyükelçilik seviyesine 1944'te çıkarılmıştır. Asgard, "U.S.-Iran," 3. 
1880'lerde ABD ve İran arasındaki ticaretin hacmi nispeten artarken, İran'ın kuzeyinde patlak veren Kürt ayaklanmalarının misyonerlerin hayatını tehlikeye atması dönüm noktası olmuş ve ABD İran' da temsilcilik açmaya karar vermiştir. ${ }^{76}$ Washington 1883 'te bir Protestan misyonerin oğlu olan Samuel G.W. Benjamin'i elçi olarak Tahran'a yollar. Benjamin, ihtişamlı törenlerle karşılanır ve hediye yağmuruna tutulur. Ancak ABD'nin temsilinde ihtişam bir yana özensizlik göze çarpmaktadır. Çok kısıtlı bir bütçe ile İran'a gönderilmiş olan Benjamin, üzerinde devasa pırlanta düğmeler olan bir cübbe giymiş Şah'ın karşısına yorgun, terli ve basit siyah bir takım elbise ile çıkmıştır. İran'ın 1888'de elçi olarak atadığı Hüseyin Ali Han Nuri ise her ne kadar "Hacı Washington" olarak adlandırılıp dönemin gazetelerinde mizah malzemesi yapılacak olsa da aslında İran'ın en köklü ailelerinden birine mensup, eski bir başbakan oğlu ve İran'ın en saygın ve tecrübeli diplomatlarından biridir. Benjamin için İran törenler düzenlemiş̧ken, Nuri’yi alt düzey bir dışişleri memuru karşılayıp yerel bir otele yerleşmesine yardımcı olmuştur. ${ }^{77}$

Diplomatik temsil anlamında ABD ve İran karşılıklı olarak başarılı olamasa da iki toplumun birbiri hakkında sınırlı bilgiye sahip oldukları bu dönemde, elçilerin gözlemleri fikirleri şekillendirmesi bakımından önemli olmuştur. Amerikan elçisi Benjamin İran'dan oldukça etkilenmiştir. 1886'da kaleme aldığ 1 "Persia and the Persians" başlıklı makalede İran'ı hem coğrafi hem de sosyolojik olarak tanıtmaya çalışan Benjamin, İran'ın Roma'dan bile önce diğerlerinden farklı bir medeniyet kurduğunu ve siyasi teşkilatlanma için sıradışı bir deha geliştirdiğini yazacaktır. İran'ın geri kalma sorununu İslam ve erişilmesi güç coğrafyası ile açıklayan elçi, bununla birlikte bilim insanlarının yokluğunu "bilimin zaten Doğunun zihin dünyasına yabancı olması”yla açıklamaya da karşı çıkmakta, İran'ın dünyanın en karanlık dönemlerinde bilimin lideri olduğunu hatırlatmaktadır. İran'ın kültüründen, sanatından, köklü geçmişinden ve Şah'ın yaşamından ve kişiliğinden etkilenmiş olan Benjamin'in en çarpıcı tespiti İran'ın geleceği üzerinedir. Eskiden yeniye geçiş döneminde olan İran'ın çektiği zorluklara, Rusya başta olmak varolan düşmanlarına karşın, süregelen bir teşkilat gücüne, güçlü kaynaklara ve hiçbir milletle baş ölçüşemeyecek dayanma gücüne sahip olduğunu söyler. "Rusya tehdit edebilir, belki bir süre kontrol

76 Ghaneabassiri, "U.S. Foreign Policy," 152; Azad, "Early US," 188.

77 Ghazvinian, America and Iran, 47. 
de edebilir ancak asla kalıcı olmaz" tespitini yapan Benjamin'e göre er ya da geç bu yüce eski insanlar, kendilerini yeniden gösterecekler, İran küllerinden daha güçlü ve muhteşem olarak doğacaktır. ${ }^{78}$

Buna mukabil İran Büyükelçisi Nuri de raporlarında da sıklıkla ABD’nin toplumsal ve siyasal sisteminden övgüyle bahseder. Amerikan teknolojisine, yollarına, köprülerine, demiryollarına hayranlık duymaktadır. Öyle ki Nuri bu hayranlığını “Allah ve Hz. Muhammed' in kast ettiği dünya nihayet meyve verdi" ${ }^{\prime 79}$ sözleri ile anlatacaktır. İran'ın ABD'ye yüklediği dengeleyici rolde ileri Amerikan teknolojinin de önemli bir yeri vardır. Bu "emperyalist olmayan" "İngiltere'den nefret eden" yeni güç, gelişmiş teknolojisi ile İran'ın ordusunu modernleştirmesine, alt yapısını yenilemesine ve güçlü bir devlete dönüşmesine yardım edebilecektir. Bilim ve sanayisini kendisi ile paylaşması, şirketlerini, tüccarlarını ve üreticilerini ülkeye göndermesi yeterlidir. ${ }^{80} \mathrm{Bu}$ Amerikan miti ülkeyi gören az sayıda ${ }^{81}$ İranlının anlatıları ile daha da kuvvetlenmiştir. "Hacı Seyyah" olarak bilinen ve 1906 Devrimi'nde kritik rol oyanayan Mirza Muhammad Ali Mahallati, ABD'ye kadar uzanan dünya turu sonunda izlenimlerini Şah Nasırüddin ile de paylaşacaktır. ${ }^{82} \mathrm{Bu}$ görüşmede neler söylendiği bilinmese de Hacı Seyyah'in 12 Haziran 1875'te Chicago merkezli Inter Ocean gazetesindeki röportajı fikir verecek niteliktedir: ${ }^{83}$

$A B D$ 'de seyahatim boyunca insanoğlunun büyük ilerlemesini gösteren pek çok muhteşem şey gördüm. Amerika'nın ortalama bilgi ve eğitim seviyesi bana göre Avrupa'daki ortalama insandan çok daha yüksek. Amerika benim için bir dünya harikasıdır. Amerika'nın Cennet bahçesi olduğunu ve Adem'in Allah'a itaat

78 Benjamin, "Persia and Persians," 27-28, 56-57.

79 Ghazvinian, America and Iran, 49.

80 A.g.e., 48.

81 19. yüzyılın ortalarından 20 yüzyılın başlarına kadar sadece 130 İranlının ABD’yi ziyaret ettiği tahmin edilmektedir. Ghaneabassiri, "U.S. Foreign Policy," 148.

82 Ali Ferdowsi, "Hajj Sayyah," Encyclopedia Iranica, Son güncelleme: 1 Mart 2012, www.iranicaonline.org/articles/hajj-sayyah.https://iranicaonline.org/articles/hajjsayyah.

83 Oryantalist ifadeler muhabirin içeriğe müdahale ettiğini düşündürse de ABD’ye hayranlığın gerçek olduğu kanaati vardır. Ferdowsi, "Conversation with"; Hamid Dabashi, Reversing the Colonial Gaze: Persian Travelers Abroad (Cambridge: Cambridge University Press, 2020), 215. 
etmediğinde günahı yüzünden Asya'ya atıldığını düşünüyorum. California bir cennet ve Kaşmir Vadisinden çok daha çekici ve güzel. ${ }^{84}$

Ancak İran'ın Amerikan teknolojisini İran'a taşıma teklifleri ABD tarafından hiç bir zaman ciddiye alınmamıştır. Hatta bu dönemde İran'ın Amerikalıların gözünde sahip olduğu, İran halılarının ve Pers tarihinin yarattı̆̆ o egzotikliğinin yanına küçümseme eklenmiştir. $\mathrm{Bu}$ aslında şaşırtıcı değildir. ABD'nin bu anlamda bakışını etkileyen Avrupalıların gözünde Kaçarlar “Doğu'nun despotları"dır. ${ }^{85}$ Nasırüddin Şah'ın 1889'da çıkacağı Avrupa gezisi öncesi Amerikan basınında "kirli despot" ve "pis hödük" gibi isimler takılan İran Şahının bir önceki İngiltere gezisindeki görgüsüzlügünü ve pisliğini anlatan öyle haberler yer alır ki İran elçisi Nuri bu aşağılamalar karşısında istifa eder. Geldiğinde hayranlık duyduğu ABD'den öfke ile ayrılır. Bu İran-ABD ilişkilerinde ne ilk ne de son hayal kırıklığıdır. ${ }^{86}$

\subsubsection{Meşrutiyetçilerin Amerikası}

1892 Tütün Ayaklanması ile büyük bir değişim süreci içine giren İran'da bu kez Şah değil Şahlık karşıtları ABD ile ilgilenmeye başlamıştır. Reformistlerin gelecekteki başbakanı Mehdikulu Han Hidayet, 19041905 yılları arasında yaptığı dünya turu sırasında tüm ABD'yi trenle gezmiştir. ${ }^{87} 1906$ 'da ülkedeki karışıklıklar sonrasında Muzafferüddin Şah Meşrutiyet ilan etmek zorunda kalınca Meşrutiyet yanlıları "aynı değerleri”" paylaştıklarını düşündükleri “demokrasinin savuncusu” ABD'den destek görecekleri inancı içine girmişlerdir. ${ }^{88} \mathrm{Bu}$ algıda misyonerler kadar İran'nın bağımsızlık mücadelesi sürecinde rol alan iki Amerikalının payı da büyüktür. Bunlardan ilki bir misyoner öğretmen olan Howard C. Baskerville diğeri ise 1911 'de yedi ay boyunca İran'da 'baş hazinedar' görevini üstlenmiş olan avukat William Morgan Shuster'dır.

\footnotetext{
84 Ali Ferdowsi, "Conversation with Hajj Sayyah," Bukhara, Haziran-Temmuz 2010, http://bukharamag.com/1389.04.2107.html\#_ftn1.

85 Ervand Abrahamian, Modern İran Tarihi (İstanbul: İş Bankası Yayınları, 2014), 12.

86 Ghazvinian, America and Iran, 49-50.

87 Nile Green, "Fordist Connections: The Automotive Integration of the United States and Iran," Comparative Studies in Society and History 58, no. 2 (2016): 296.

88 Bonakdarian, “U.S.-Iranian Relations,” 10-12.
} 
1906'da Tebriz'e gelen Baskerville, İran kültüründen ve İran'daki meşrutiyet hareketinden bu uğurda savaşacak kadar etkilenmiştir. Baskerville çoğu kendi öğrencisinden oluşan bir alay kurar ve 1909'daki Tebriz İsyanı sırasında öldürülür. Bu olay "Amerikalı şehit" olarak anılacak Baskerville'i bir kahramana dönüştürürken, cenazesine binlerce İranlı katılır. ${ }^{89}$ ABD'nin sıklıkla demokrasi ve özgürlük hareketlerinin yanında olduğunu dile getirdiği bir dönemde bir Amerikalının İran'ın bağımsızlığı için can vermesi son derece etkileyici bir hadisedir. Ancak bu olay ABD'nin İran'a ve İranlı reformistlere bakıșını hiçbir şekilde yansıtmamaktadır. İran'daki Amerikan temsilciliği 1906'da Dışişlerine gönderdiği durum raporunda, Şah'ın tebaasının büyük kısmının anayasanın anlamını bilmediğini, halkın büyük çoğunluğunun eğitimsiz olduğunu ve devletin dinin İslam olduğu bir ülkede tarihin bir kez bile başarılı bir anayasal hükümet örneği kaydetmediğini yazmıştır. Amerikan Dışişleri Baskerville ve ayaklanmaya destek veren misyonerlerin yanında olmak bir yana, İngiltere ile arasında sorun yaratabileceği için bu durumdan rahatsızlık bile duymaktadır. Elçiye meşrutiyete destek olan hiç kimsenin korunmayacağı bildirilir. ABD, İran'da ilk Meclis açıldıktan sonra da yeterince güçlü görmediği bu yeni yönetimi tanıma konusunda terreddüt edecektir. $^{90}$

1909'da Meşrutiyetçiler zafer kazanıp, meclisi yeniden açtıklarında karşılarındaki en büyük sorun maliyeyi düzeltmek olmuştur. İran bir kez daha bu sefer ekonomisini toparlama gayesi ile yüzünü ABD'ye dönecektir. Diğer ülkelerden yardım almak düşünüldüyse de ABD, İran'da siyasi ve ekonomik çıkarları olmadığ Bu fikir hem meclis içinde hem meclis dişında destek bulmuştur. ABD'nin "güçlü bir dürüstlük anlayışını rehber edinmiş, çalışkan ve müreffeh" bir ülke olduğunu düşünen Meşrutiyet yanlılarına göre bir kaç "iyi ve dürüst" Amerikalı ülkeye düzeni getirebilecektir. ${ }^{92}$ Yeni hükümet ayrıca, Amerikalı danışmanlar istihdam edilirse ekonomik toparlanmanın yanı sıra ABD'nin Avrupa ile arasında bir denge ve tampon haline geleceğini ve bunun İran için güçlenip, ayağa kalmak ve bağımsızlığ korumak adına firsat yaratacağını düşünmektedir. ${ }^{93}$

\footnotetext{
89 Asgard, "U.S.-Iran," 3-4; Azad, "The Legacy,” 201.

90 Ghaneabassiri, "U.S. Foreign Policy," 151-154.

91 Ansari, Modern Iran, 110.

92 Ghazvinian, America and Iran, 69.

93 Azad, "Early US," 191.
} 
$\mathrm{Bu}$ teklif ilk geldiğinde Amerikan hükümeti son derece temkinli yaklaşmış ancak İngiltere ve Rusya'nın itirazları olmadığını görünce kendince bir orta yol bularak İran'nn talebine 1911'de olumlu cevap vermiştir. Danışman olarak seçilen William Morgan Shuster İran'a resmi bir görevle gönderilmeyecek, bir sivil olarak İran hükümeti tarafindan üç yıllığına işe alınacaktır. Görevinin Amerikan devleti ile hiçbir resmi bağlantıs1 yoktur. Ancak buna rağmen Shuster'1n gönderilmesi ABD'nin İran'ın bağımsızlığını ve liberalleşme sürecini desteklediği kanaatini ülke içinde daha da güçlendirecektir. ${ }^{94}$ Shuster'in statüsü ne olursa olsun ABD'nin katı izolasyoncu politikasını delip İngiltere ve Rusya'nın nüfuz bölgesine temkinli adımlarla girişinin birkaç nedeni vardır. Her ne kadar Bonakdarian 19. yüzyılda ABD'nin misyonerlerin güvenliği dışında İran'a karşı bir ilgisi olmadığın1 ${ }^{95}$ söyle de aslında bu durum yüzyıl sonunda dünya politikasıyla birlikte değişim yoluna girmiştir. $\mathrm{Bu}$ dönemde dünyanın en güçlü ekonomisine sahip ABD'nin içerideki üretim fazlası ve yeni pazarlar arayışı dış politikası üzerinde baskı oluşturmaya başlamıştır. Amerikan denizaşırı emperyalizminin başlangıcı kabul edilen 1898 İspanyol-Amerikan Savaşı sonrasında $\mathrm{ABD}$ artık dünyanın geri kalanına o kadar ilgisiz değildir. 1901'de başkanlığa seçilen Theodore Roosevelt, Amerika'nın alışılageldik imparatorluk karşıtı duruşunu bir yana bırakacak ve açık bir dille Avrupa tarzı emperyalizmini savunacaktır. Bu nedenle 1900'de İran Dışişleri Bakanı Washington'ı ziyaret ettiğinde Amerikalı iş adamlarının artan yoğun ilgisi dikkat çekicidir. 200'den fazla iş adamı kendisine İran'la ticaret yapmak istediğini söylemiştir. ${ }^{96}$ Ayrıca ABD'nin İran petrolüne olan ilgisi de artmıştır. Amerikalılar da diğer büyük güçler gibi Ortadoğu'nun farklı yerlerlinde petrol imtiyazları elde etmeye çalışmaktadırlar. Her ne kadar İran hükümeti petrolün 60 y1llık hakkını İngiliz vatandaşı olan William Knox D'Archy'e satmış olsa da 1908'de Abadan'ın kuzeybatısında yeni petrol yatakları keşfedilmiştir. ${ }^{97}$ Tüm bu gelişmeler içinde İran eskisi kadar kolay göz ardı edilen bir ülke olmaktan çıkmıştır.

\footnotetext{
94 Ghaneabassiri, “U.S. Foreign Policy,” 155-156.

95 Bonakdarian, "U.S.-Iranian Relations," 11.

96 Ghazvinian, America and Iran,58; Azad, "Early US," 185.

97 Azad, "Early US," 190.
} 
William Morgan Shuster Mayıs 1911'de başladığı 'baş hazinedarlık' görevi boyunca İran'ın mali bağımsızlığını kazanmasına yönelik gerçek bir çaba göstermiş ve İran halkının saygısını kazanmıştır. ${ }^{98}$ Ancak ekonomik çıkarları zedelendiği için çalışmaları kısa bir süre sonra hem İngiltere'nin hem de Rusya'nın sert tepkisine neden olmuştur. Shuster'ın gitmesini isteyen Rusya'nın Kasım 1911'de verdiği ültimatom ile İran'1 işgal tehditleri karş1sında Meclis direnecek ve Aralık 1911'de ültimatomu reddedecektir. Bu arada hem Shuster hem İran Meclisi yardım için Amerikan Kongresi'ni ikna çabası içine girmişlerdir. İran Meclis Başkanı'nın Amerikan Kongresi'ne gönderdiği mektup ABD'nin demokrasinin ve özgürlüklerinin koruyucusu imajının ne kadar güçlü olduğunu göstermektedir:

Özgürlügüü faydalarını tatmışolan sizler, tek hatası kendigeleceğini kurtarmak için sizin sisteminize yakınlık duyan bir ulusun yıkılışına şahitlik eder misiniz? Iran ulusal haysiyetini korumak istediği için ve özgür bir halk için çok değerli olan duyguları anlamış olduğu için yıkılırsa, bunun için acı çeker misiniz? Temsilcisi olduğunuz cömert halkın onur ve adalet duygularına güvenerek, eminiz ki ricamı doğrudan kulaklarınıza nüfuz edecektir ve bize Iran'in şerefine ve bă̆ımsızlı̆̆ına uygun bir çözüm içinde sözü geçen yardımı sağlayacaktır. ${ }^{99}$

Amerikan Dış İlişkiler Komitesi Shuster'ın eylemlerini savunmayı bir süre düşündüyse bile Kongre ABD'yi olayların dışında tutmayı tercih edecektir. Mektuba bir cevap bile gönderilmemiştir. ${ }^{100}$ Destek bulamayan Shuster ülkesine dönerken, Rusya İran'1 işgal edecek ve Meclisi kapatıracaktır.

Ghaneabassiri, Meşrutiyetçilerin Amerika'dan destek görecekleri hatasına sürükleyen şeyin, ABD'nin kamuoyu önünde dile getirdiği idealler ile Amerikan dış politikasının aynı şeyler olmadığının farkına varmamaları olduğunu söyler. ${ }^{101}$ Bunu farketmeleri de aslında hiç kolay değildir. Amerikan basını sürecin başından itibaren İran'daki meşrutiyet hareketine büyük yer vermiş ve sempati göstermiştir. New York Times, Nation, Independent ve Outlook'ta meşrutiyetçilere destek veren yazılar

\footnotetext{
98 Ansari, Modern Iran, 110-111; Asgard, "U.S.-Iran," 3.

99 Ghaneabassiri, "U.S. Foreign Policy," 158.

100 Bonakdarian, "U.S.-Iranian Relations," 11; Ghaneabassiri, “U.S. Foreign Policy,” 158.

101 Ghaneabassiri, "U.S. Foreign Policy,” 153-154.
} 
yayınlanmıştır. ${ }^{102}$ Bir iş adamı olan W. P. Cresson basının İran'daki gelişmelere gösterdiği ilgiyi görüp İran'la ilgili bir kitap olmadığını farkederek $^{103} 1908$ 'de birkaç y1l önce gittiği İran'daki gözlemlerine dayanan Persia: Awakening East kitabını yayınlayacaktır. Kitap, İran'daki güncel siyasi durumu anlatmasa da içerdiği İran ve İranlılara dair pek çok fotoğraf Amerikalılar için İran'ın canlı bir tasvirini sunmuştur. Basının ilgisi Shuster'ın İran'a gönderilmesi ile daha da artmıştır. Gazetelerde beş genç yankee'nin kahramanca kadim fakat monarşiden yeni uyanan bir halka yardım etmeye gidişi anlatılmaktadır. Aslında Amerikalıların çoğunun İran hakkında bilgisi hala çok azdır. Daha çok ilgi çeken Shuster üzerinden Avrupa'nın büyük güçleri karşında ezilen bir halka yardım eden ABD hikayesidir. Dönüşünde Shuster ülkesinde bir ulusal kahraman olmuştur. ${ }^{104}$ Bu nedenle Shuster'ın 1912'de yayınlanan Strangling of Persia kitabı çok okunacaktır. Kitapta Shuster'ın İran'1, Amerikalı okuyucuya kolaylıkla tanıdık gelecek olan bir hikaye ile emperyal güçler tarafindan tehdit edilen genç demokratik bir ulus olarak resmetmiş olması önemlidir. ${ }^{105}$ Shuster'ın konuşmaları ve yazıları Amerikan kamuoyunda İran'a ve meşrutiyetçilere duyulan sempatiyi artırırken ABD-İran ilişkileri adına bir anlamda dönüşü, gidişinden daha yapıcı etkiler bırakmıştır. ${ }^{106}$

Birinci dünya savaşı arifesinde $\mathrm{ABD}$ için İran, Amerikan halkının duymaya başladığı yakınlığa, ABD'nin artan ticari ilgisine rağmen hala uzaktaki bir ülkedir. İran için ise ABD her anlamda firsatlar ülkesidir. Şah Ahmed Mirza, 1911'de henüz 13 yaşındayken New York Times'a verdiği röportajda aslında ABD'yi değil bu Amerikan rüyasını anlatacaktır:

Elbette Amerikalıları seviyorum. Özgürlük için savaştılar.. pek çok kahramanca şey yaptılar. Harika makinaların mücitleri... Amerika elektirikle her şeyin yapıldiğı bir yer.... insanların çok özgür olduğu bir yer. ${ }^{107}$

\footnotetext{
102 Bonakdarian, "U.S.-Iranian Relations," 11.

103 William Penn Cresson, Persia: The Awakening East (Philadelphia and Londra: J.B. Lippincott, 1908), 12.

104 Ghazvinian, America and Iran, 75.

105 Green, "Fordist Connections," 295.

106 Ghaneabassiri, "U.S. Foreign Policy," 153-154.

107 Ghaneabassiri, "U.S. Foreign Policy,” 150, "Boy Shah Likes Americans," New York Times, 20 Ağustos 1911.
} 


\section{Sonuç}

"Zamanların en iyisiydi, zamanların en kötüsüydü; bilgelik çağıydl, ahmaklık çağıydl; inanç devriydi, inançsızlık devriydi; aydınlık mevsimiydi, karanlık mevsimiydi; umudun baharlydl, umutsuzluğun kışıdl; önümüzde her şey vardl, önümüzde hiçbir şey yoktu" 108 satırları ile açılır Charles Dickens'in İki Şehrin Hikayesi romanı. Romanda konu edilen Fransız Devrimi sırasinda Londra ve Paris olsa da bu satırlar, 1800'lü yıllardan I. Dünya Savaşına uzanan dönemde başka iki şehrin, Washington ve Tahran'ın hikayesinin yazıldığı ortamı da özetler niteliktedir. Yeni dünyada bir güç yükselirken, eski dünyada bir güç batmaktadır. Bir taraf yeniyi, modernliği, teknolojiyi temsil ederken, öteki taraf eskiyi, köklü bir tarihi, kadim bir geleneği temsil etmektedir. Değişim, dönüşüm ve peşi sıra kargaşa ve çatışmaların hakim olduğu bu dönem içinde birbirlerine karşı hiçbir tecrübesi olmayan bu iki ülkenin ilişkilerinde henüz kızgınlıklar yoktur ve cehaletin getirdiği bir masumiyet içinde her şey mümkündür; ilişkiler umut vadetmektedir. Hatta bu cehalete rağmen değil biraz bu cehalet sayesinde birbirlerini görmek istedikleri gibi göreceklerdir. Öte yandan yine bu yüzden pek çok şey de imkansızdır.

Dönemin Amerikan imajını büyük ölçüde inşa eden ABD’nin İranüzerindeki politikaları değil, ülkede bulunan Amerikan misyonerlerinin özellikle eğitim ve sağlık alanındaki faaliyetleri olmuştur. Bu Amerika iyiliksever, monarşiye karşı savaşmış, diğer Batılı büyük güçlere benzemeyen ve İran'da emperyalist gayeleri olmayan bir ülkedir. Teknolojik gelişmişliği, çalışkanlığ 1 ve azmi temsil etmektedir. Bu imaj dönemin konjönktürü ile birleşince ABD, İran'ın gözünde İngiltere ve Rusya'ya karşı ittifak kurulabilecek, hiç değilse İran'ın yanında durarak modernleşmesini sağlayacak ve bu güçleri dengeleyek bir güç haline gelmiştir. 1906 Devrimi sürecinde ABD'nin "özgürlük ve demokrasi savuncusu” imajı Baskerville ve Shuster gibi Amerikalıların kişilikleri üzerinden daha da güçlenmiştir. Bu da İran'1 ABD'yle ilgili karşılanmayan beklentiler içine sokmuştur. Her ne kadar ABD'nin kurucu bir demokrasi söylemi ve 1845 'ten itibaren demokrasi götürme anlayışı olsa da bu söylem, Wilson İlkelerine kadar kıtadan çıkıp, küresel bir hal almamıştır. 19. yüzyıl sonunda görmeye başladığı ticari potansiyel sayılmazsa, ABD'nin İran'a karşı ilgisi yok

108 Charles Dickens, A Tale of Two Cities (Londra: Penguin Books, 1994), 13. 
denecek kadar azdır. Amerikan Devleti için İran, İngiltere ve Rusya'nın nüfuz mücadelesi altında olan kendisi için tehlikeli topraklardır.

Amerikan toplumunda ve devletinde İran'a kıyasla bilgi erişimi daha fazla olmasına karşın, şaşırtıcı derece İran'ı tanıma ve anlama konusunda onlar da yetersiz kalmışlar ve hata içine düşmüşlerdir. ABD'de İran imajını yaratan en önemli kanallardan biri yine Amerikan misyonerleridir. Misyonerlerin püriten bakış açıları ve Amerikalıların İran hakkındaki az bilgilerini de İncil'den edinmiş olmaları, İran'ın Şiiliği ile birleşince İran Ortadoğu'nun daha az müslüman, daha az Arap toplumuna dönüşmüştür. İslam'a dair sahip olunan derin ön yargılar, İran kültürüne ve toplumuna duyulan hayranlık ile adeta çatışma içine girmiş ve İranlı kimliğinin büyük bir parçası olan İslam bu nedenle Amerikalıların İran imajında adeta ötekileşmiştir. 1906 Devrimi’nin monarşi karşıtı duruşu ve Amerikan basınına yansıması, "genç bir demokrasiye yardım eden ABD" söylemi üzerinden Amerikan toplumu gözünde İran'1 Ortadoğu'da ayrıcalıklı bir yere koymuştur. Amerikan misyonerlerinin ABD-İran ilişkilerinde üstelendikleri diplomatik roller göz önüne alındığında bütün bu algıların devlet düzeyinde İran'a bakışı etkilemediği söylenemez. Ancak bu etki daha uzun vadede kendini gösterecektir.

$\mathrm{Bu}$ karşıllklı imajlar ilişkilerin ileriki yıllarına da göreceli olarak taşınmıştır. Nitekim üstüne ne kadar bilgi eklense de, "İran'da çıkarları olmayan, emperyalizm karşııtı bir güç olan" ABD ile "o kadar da Müslüman olmayan, köklü, Doğu'nun mücadele veren genç demokrasisi” İran arasındaki ilişkiler, ABD'nin emperyal, İran'ın ise "çok Müslüman" olduğu gerçeği ile belki de bu yüzden karşılıklı şaşkınlık ve hayal kırıklığı içinde dağılacaktır.

\section{Kaynakça}

Abrahamian, Ervand. Modern İran Tarihi. İstanbul: İş Bankası Yayınları, 2014.

Alexander, Michele G., Shana Levin ve P. J. Henry. "Image Theory, Social Identity, and Social Dominance: Structural Characteristics and Individual Motives Underlying International Images." Political Psychology 26, no. 1 (2005): 27-45. 
Amanat, Abbas. Pivot of the Universe: Nasir al-Din Shah Qajar and the Iranian Monarchy ((1831-1896). Londra: I.B. Tauris, 1997.

Ansari, Ali M. Modern Iran since 1797: Reform and Revolution. New York: Routledge, 2019.

Asch, Solomon. Social Psychology. Englewood Cliffs, NJ: Prentice Hall, 1952.

Asgard, Ramin. "U.S.-Iran Cultural Diplomacy: A Historical Perspective." Al Nakhlah (Bahar 2010). https://ciaotest.cc.columbia.edu/journals/ aln/aln690/f_0019356_16566.pdf.

Azad, Abul Kalam. "Early US Economic Involvement in Iran." Probandha Sankolon /A Compilation of Essays, no. 4 (Ocak 2019): 185-196.

Azad, Abul Kalam. "Iran-US (United States) Relations Since 1945." Doktora Tezi, University of Dhaka, 2017.

Azad, Abul Kalam. "The Legacy of the American Presbyterian Mission in Iran." Journal of the Asiatic Society of Bangladesh 58, no. 1 (2013): 192-205.

Benjamin, Samuel G. W. "Persia and the Persians." Journal of the American Geographical Society of New York 18, (1886): 27-66.

Bill, James A. The Eagle and the Lion: The Tragedy of American Iranian Relations. New Haven: Yale University Press, 1989.

Bonakdarian, Mansour; "U.S.-Iranian Relations, 1911-1951," içinde The United States and the Middle East: Diplomatic and Economic Relations in Historical Perspective. Editör: Abbas Amanat, 9-25. New Haven: Yale University Press, 2000.

Boulding, Kenneth Ewart. "National Images and International Systems." The Journal of Conflict Resolution 3, no. 2 (June 1959): 120-131.

Browne, Edward Granville. A Year Amongst the Persians: Impressions as to the Life, Character \& Thought of the People of Persia, Received During Twelve Months' Residence in That Country in the Years 18871888. Londra: Adam and Charles Black, 1893.

Cresson, William Penn. Persia: The Awakening East. Philadelphia and Londra: J.B. Lippincott, 1908. 
Dabashi, Hamid. Reversing the Colonial Gaze: Persian Travelers Abroad. Cambridge: Cambridge University Press, 2020.

Dickens, Charles. A Tale of Two Cities. Londra: Penguin Books, 1994.

Fisher, Glen. Mindsets: The Role of Culture and Perception in International Relations. Yarmouth: Intercultural Press, 1997.

Ghaneabassiri, Kamyar. "U.S. Foreign Policy and Persia, 1856-1921." Iranian Studies 35, no. 1/3 (2002): 145-175.

Ghazvinian, John H. America and Iran: A History 1720 to Present. Londra: Oneworld Publications, 2020.

Gheissari, Ali. "The American College of Tehran, 1929-32: A Memorial Album," Iranian Studies 44, no. 5 (2011): 671-714.

Green, Nile. "Fordist Connections: The Automotive Integration of the United States and Iran," Comparative Studies in Society and History 58, no. 2 (2016): 290-321.

Herrmann, Richard K. "Image Theory and Strategic Interaction in International Relations." içinde Oxford Handbook of Political Psychology, Editörler: D. O. Sears, L. Huddy ve R. Jervis, 285-314. Oxford: Oxford University Press, 2003.

Herrmann, Richard K., James F. Voss, Tonya Y. E. Schooler ve Joseph Ciarrochi. "Images in International Relations: An Experimental Test of Cognitive Schemata." International Studies Quarterly 41, no. 3 (1997): 403-33.

Holmes, Oliver Wendel. The Autocrat of the Breakfast Table. Boston: James R. Osgood and Company, 1873.

Jervis, Robert. Perception and Misperception in International Politics. Princeton, N.J.: Princeton University Press. 2017.

Maalouf, Amin. Semerkant. İstanbul: Yap1 Kredi Yayınları, 1998.

Owen, John M. "How Liberalism Produces Democratic Peace." International Security 19, no. 2 (1994): 87-125.

Rock, Irvin ve Stephen Palmer. "The Legacy of Gestalt Psychology." Scientific American 263, no. 6 (1990): 84-91. 
Rostam-Kolayi, Jasamin. "From Evangelizing to Modernizing Iranians: The American Presbyterian Mission and Its Iranian Students." Iranian Studies 41, no. 2 (2008): 213-239.

Wytenbroek, Lydia. "Generational Differences: American Medical Missionaries in Iran, 1834-1940." içinde Iran and the West: Cultural Perceptions from the Sasanian Empire to the Islamic Republic, Editörler: David Bagot ve Margaux Whiskin, 179-194. Londra ve New York: I.B. Tauris, 2018.

Yerdelen, Betül Karagöz. "Uluslararası İlişkilerde İmaj Kavramı ve Batı Nostaljisindeki Bir Aksaklık Olarak Türk İmaj1." Karadeniz Uluslararası Bilimsel Dergi 35, no. 35 (2017): 43-63.

Zinn, Howard. Amerika Birleşik Devletleri Halklarının Tarihi. Ankara: İmge Kitabevi, 2005.

Zirinsky, Michael P. "Render Therefore Unto Caesar the Things Which Are Caesar's: American Presbyterian Educators and Reza Shah." Iranian Studies 26, no. 3/4 (1993): 337-56.

Zirinsky, Michael P. "A Panacea for the Ills of the Country: American Presbyterian Education in Inter-War Iran." Iranian Studies 26, no. 1/2 (1993): 119-137.

\section{Internet Kaynakları}

Amatbek, Dinmuhammed. "Perception and Image Theory of International Relations." Ankasam, 24 Haziran 2017. https://ankasam.org/en/ perception-and-image-theory-of-international-relations/\#_edn1 .

"Cyrus Cylinder: How a Persian monarch inspired Jefferson." BBC News. 11 Mart 2013. https://www.bbc.com/news/world-us-canada-21747567.

Ferdowsi, Ali "Conversation with Hajj Sayyah.” Bukhara, Haziran-Temmuz 2010. http://bukharamag.com/1389.04.2107.html\#_ftn1.

Ferdowsi, Ali. "Hajj Sayyạ̣.” Encyclopedia Iranica. Son güncelleme: 1 Mart 2012. www.iranicaonline.org/articles/hajj-sayyah.

Frye, Richard N. "Jefferson And Cyrus: How The Founding Fathers of America, in Their Own Words, were Inspired by Cyrus the Great." 
2013. http://richardfrye.org/files/Thomas_Jefferson_and_Cyrus_the Great.pdf.

Library of Congress. "Iran: Friendship and Commerce." 13 Aralık 1856. Son erişim: 16 Şubat 2021. https://www.loc.gov/law/help/us-treaties/ bevans/b-ir-ust000008-1254.pdf

United States Senate. "George Washington Farewell Address." Son erişim: 08 Şubat 2021. https://www.senate.gov/artandhistory/history/ resources/pdf/Washingtons_Farewell_Address.pdf 
